\title{
IMMOBILIZATION OF THE KNEE JOINT IN RHEUMATOID ARTHRITIS
}

\author{
BY \\ R. HARRIS AND E. P. COPP \\ Devonshire Royal Hospital, Buxton, and Manchester Royal Infirmary
}

Local rest of actively involved joints in plaster of paris splints plays an important part in the conservative treatment of rheumatoid arthritis. It has been accepted practice for many years that such joints should be rested, but considerable disagreement exists as to how complete this immobilization should be. Although lip-service is paid to the concept of continuously splinting an active joint, splintage is usually intermittent. Because of the fear of ankylosis occurring in such joints, it is insisted that the joint be moved daily (or more frequently) through the maximum range permitted by pain.

It has been our practice to immobilize painful active rheumatoid arthritic knee joints continuously for periods up to 4 weeks. The following experiment was undertaken to estimate the safety of this technique and any advantages it may have in comparison with intermittent splintage.

\section{Material}

All patients with definite rheumatoid arthritis and actively and fairly symmetrically involved knee joints, who were admitted as in-patients to the Rehabilitation Unit of the Devonshire Royal Hospital during a 12-month period, were considered for the trial. The following criteria were used:

Diagnosis.-The subjects selected were all "definite R.A." according to the classification of the American Rheumatism Association, and in 90 per cent. the sheep cell agglutination test was positive. Subjects with Still's disease were excluded.

Symmetry.-All subjects had to have both knees involved to approximately the same degree, not differing by more than one grade of activity (see below). All joints had to be painful, thickened, and tender, but not clinically or radiologically ankylosed.

Deformity.-Subjects with flexion deformities exceeding $10^{\circ}$ were excluded from the trial.
During the 12-month period over 200 patients with rheumatoid arthritis were seen; 21 of these were selected for the trial, but only eighteen completed the assessment period with all the necessary tests and assessments.

\section{Method}

For each patient the usual social data was recorded and a detailed medical history which included duration of disease, duration of each knee involvement, general and local activity of the disease, sheep cell agglutination test, erythrocyte sedimentation rate, and particulars of any steroid therapy administered.

Each patient was graded and assessed before the trial started and then on "day 0" both knees were immobilized in full-leg, unpadded plaster casts in a position as near to neutral as possible. At random, one plaster of each pair was split on the fourth day, and daily movements of this joint were undertaken with the help of a physiotherapist, the joint being moved through its maximum range within the limits of pain, and the limb being returned to the split plaster after about 10 minutes. The other plaster was not split for 4 weeks. If at this stage, the knees were pain-free, the plasters were discarded, but if pain was present they were retained as rest plasters. Otherwise, during the whole period of the experiments the patient continued her usual programme of rest, exercises, and appropriate physical and systemic therapy, No particular exercise or therapy was directed at the knees, although each patient did quadriceps setting regularly as part of the daily routine. During the period of immobilization, and during the assessment stage, walking was permitted unless contraindicated by pain on weight-bearing or general disease activity. Intraarticular steroids were not used.

The knees were assessed at $0,4,5,6$, and 8 weeks.

\section{Assessment}

(1) Pain on Passive Movement:

$$
\begin{aligned}
\text { Grade } 0 & =\text { No pain, } \\
1 & =\text { Slight pain, } \\
2 & =\text { Moderate pain, } \\
3 & =\text { Severe pain, or pain when at rest. }
\end{aligned}
$$


(2a) Swelling of the Knee:

Grade $0=$ No swelling,

$1=$ Thickening,

$2=$ Small effusion,

$3=$ Large effusion.

(2b) Knee Girth:

This was measured in $\frac{1}{4}$ inches at the proximal pole of the patella.

(3) Thigh Circumference:

This was measured in $\frac{1}{4}$ inches 6 inches proximal to the upper pole of the patella.

(4) Ligamentous Laxity:

Antero-posterior assessed with knee flexed; lateral with knee extended:

Grade 0 = None,

$$
\begin{aligned}
& 1=\text { Trace, } \\
& 2=\frac{1}{2} \text { in. or } 10^{\circ}, \\
& 3=>2 .
\end{aligned}
$$

(5) Local Activity of Disease in the Knee:

Grade 0 No involvement,

$1=$ Minor: tender + , pain on use,

2 - Moderate: tender + or ++ , pain on use and at rest,

3 = Severe: tender ++ , heat + , pain at rest $t$, pain on use ++ , thickening + or ++ .

(6) Knee Range:

This was measured in degrees with a long-arm goniometer (Passive).

(7) Erythrocyte Sedimentation Rate (Westergren):

This was measured on the same day as each assessment.

(8) Radiological Grading:*

$X$ rays were taken at the beginning of the investigation.

Grade 0 = Normal,

$1=$ Osteoporosis,

2 = Osteoporosis, some erosions, and/or reduction in joint space,

3 = Osteoporosis, erosions, reduced joint space, cartilage loss.

(9) Disease Activity:

The general level of disease was graded 0-3 at the beginning of experiment, and the following were also noted:

(a) Sheep cell agglutination test: Recorded as positive or negative.

(b) Steroid therapy: whether or not the patient was taking steroids.

(c) Patient's preference: whether the patient preferred the immobilized or partially immobilized side.

* Any pat:ont showing Grade 4 (ankylosis) was excluded from the series.

\section{Results}

Eighteen subjects were completely assessed. Three $\underline{\square}$ others completed the assessment period but are $\stackrel{\bar{\rho}}{\text { ? }}$ omitted, two because the $x$ rays of knees were not $\overrightarrow{\bar{c}}$ taken immediately before the experiment, and the other because the S.C.A.T. was not recorded. The major particulars are given in Table I (opposite), $\overline{\bar{N}}$ which shows that there were four males and fourteen $\overrightarrow{\mathbb{\Phi}}$ females, whose ages ranged from 19 to 69 years (mean 52).

\section{Findings}

The sheep cell agglutination test was positive in sixteen subjects, among whom was the patient withis the greatest loss of mobility after fixation.

Eleven patients were taking steroids and seveniw were not.

The administration of steroids apparently had no응 influence on the resulting knee mobility. The threesubjects with the greatest loss of mobility were allo taking steroids, but major losses also occurred in patients not taking steroids. No conclusions can therefore be drawn.

The duration of disease varied from less than one year to 26 years. In the three subjects with diseses of less than 1 year's duration (Cases $3,8,9$ ), the was no real loss of joint mobility. Of the five paris of knees with clinical involvement of less than ones year (Cases 1, 3, 8, 9, 15), only one pair had lost any movement (Case 1: loss of $15^{\circ}$ and $10^{\circ}$ ), an $\AA^{\circ}$ two pairs showed major gains (Cases 8, 9). How $\frac{\pi}{2}$ ever, the pairs of knees showing the greatest loss in mobility (Cases 6 and 11) had been involved onlys for 2 years.

\section{Patients' Preference}

Five patients preferred the complete plaster seven preferred partial immobilization, and the other six expressed no preference or their replys was not noted.

\section{Objective Observations}

(1) Pain.-That experienced by the patient during the first 4 weeks was not charted. The intervat findings were assessed in four grades as in Table $I \leqslant, \omega$ which shows the distribution of each grade of paip at each assessment. A total "pain score" for eacto period was obtained by multiplying the number of patients in each grade by the numerical value of the grade. 
TABLE I

SUMMARY OF RESULTS IN EIGHTEEN SUBJECTS

\begin{tabular}{|c|c|c|c|c|c|c|c|c|c|c|c|c|c|}
\hline \multirow{3}{*}{$\begin{array}{l}\text { Case } \\
\text { No. }\end{array}$} & \multirow[b]{3}{*}{ Sex } & \multirow{3}{*}{$\begin{array}{c}\text { Age } \\
\text { (yrs) }\end{array}$} & \multicolumn{4}{|c|}{ General Clinical Particulars } & \multicolumn{7}{|c|}{ Knees } \\
\hline & & & \multirow[b]{2}{*}{$\begin{array}{c}\text { Dura- } \\
\text { tion of } \\
\text { Disease } \\
\text { (yrs) }\end{array}$} & \multirow[b]{2}{*}{$\underset{\text { Test }}{\text { S.C.A. }}$} & \multirow[b]{2}{*}{$\begin{array}{l}\text { Steroid } \\
\text { Therapy }\end{array}$} & \multirow[b]{2}{*}{$\begin{array}{l}\text { Grade of } \\
\text { General } \\
\text { Disease } \\
\text { Activity }\end{array}$} & \multirow[b]{2}{*}{$\begin{array}{c}\text { Dura- } \\
\text { tion of } \\
\text { Disease } \\
\text { (yrs) }\end{array}$} & \multicolumn{3}{|c|}{ Immobile } & \multicolumn{3}{|c|}{ Mobile } \\
\hline & & & & & & & & $\begin{array}{l}\text { Radio- } \\
\text { logical } \\
\text { Grading }\end{array}$ & $\begin{array}{l}\text { Grade of } \\
\text { Local } \\
\text { Disease } \\
\text { Activity }\end{array}$ & $\begin{array}{l}\text { Change in } \\
\text { Range of } \\
\text { Movement } \\
\left({ }^{\circ}\right)\end{array}$ & $\begin{array}{l}\text { Radio- } \\
\text { logical } \\
\text { Grading }\end{array}$ & $\begin{array}{l}\text { Grade of } \\
\text { Local } \\
\text { Disease } \\
\text { Activity }\end{array}$ & $\begin{array}{l}\text { Change in } \\
\text { Range of } \\
\text { Movement } \\
\left({ }^{\circ}\right)\end{array}$ \\
\hline $\begin{array}{r}1 \\
2 \\
3 \\
4 \\
5 \\
6 \\
7 \\
8 \\
9 \\
10 \\
11 \\
12 \\
13 \\
14 \\
15 \\
16 \\
17 \\
18\end{array}$ & $\begin{array}{l}\mathbf{F} \\
\mathbf{F} \\
\mathbf{M} \\
\mathbf{F} \\
\mathbf{F} \\
\mathbf{F} \\
\mathbf{M} \\
\mathbf{F} \\
\mathbf{F} \\
\mathbf{F} \\
\mathbf{F} \\
\mathbf{F} \\
\mathbf{F} \\
\mathbf{F} \\
\mathbf{M} \\
\mathbf{F} \\
\mathbf{F} \\
\mathbf{M}\end{array}$ & $\begin{array}{l}51 \\
59 \\
52 \\
45 \\
62 \\
69 \\
58 \\
35 \\
64 \\
60 \\
57 \\
55 \\
63 \\
60 \\
54 \\
19 \\
63 \\
48\end{array}$ & $\begin{array}{r}26 \\
8 \\
<1 \\
17 \\
6 \\
3 \\
2 \\
<1 \\
<1 \\
5 \\
3 \\
5 \\
11 \\
15 \\
10 \\
9 \\
10 \\
7\end{array}$ & $\begin{array}{l}+ \\
+ \\
+ \\
+ \\
+ \\
+ \\
+ \\
+ \\
+ \\
+ \\
+ \\
+ \\
+ \\
+ \\
+ \\
+ \\
+ \\
+\end{array}$ & $\begin{array}{l} \pm \\
\pm \\
\pm \\
+ \\
+ \\
+ \\
+ \\
+ \\
+ \\
+ \\
\pm \\
+ \\
+ \\
+ \\
+ \\
-\end{array}$ & $\begin{array}{l}2 \\
2 \\
2 \\
3 \\
2 \\
2 \\
2 \\
3 \\
2 \\
2 \\
2 \\
2 \\
2 \\
3 \\
3 \\
3 \\
2 \\
2\end{array}$ & $\begin{array}{r}<1 \\
8 \\
<1 \\
16 \\
1 \\
2 \\
2 \\
<1 \\
<1 \\
2 \\
2 \\
4 \\
8 \\
8 \\
<1 \\
3 \\
2 \\
7\end{array}$ & $\begin{array}{l}0 \\
0 \\
0 \\
1 \\
1 \\
1 \\
1 \\
1 \\
1 \\
1 \\
2 \\
1 \\
2 \\
2 \\
2 \\
2 \\
2 \\
3\end{array}$ & $\begin{array}{r}2 \\
1 \\
1 \\
2 \\
2 \\
2 \\
2 \\
2 \\
2 \\
1 \\
2 \\
2 \\
2 \\
2 \\
2 \\
2 \\
2 \\
1 \\
3 \\
3 \\
3 \\
2\end{array}$ & $\begin{array}{r}-15 \\
+15 \\
-5 \\
-5 \\
0 \\
-40 \\
-20 \\
+45 \\
+25 \\
+10 \\
-70^{*} \\
+15 \\
-30 \\
-5 \\
+5 \\
+10 \\
+5 \\
-25\end{array}$ & $\begin{array}{l}0 \\
1 \\
0 \\
1 \\
1 \\
1 \\
1 \\
1 \\
1 \\
1 \\
1 \\
1 \\
2 \\
2 \\
2 \\
2 \\
3 \\
2\end{array}$ & $\begin{array}{l}2 \\
2 \\
2 \\
2 \\
2 \\
2 \\
2 \\
1 \\
2 \\
2 \\
2 \\
2 \\
2 \\
2 \\
1 \\
3 \\
2 \\
2\end{array}$ & $\begin{array}{r}-10 \\
+35 \\
+10 \\
+25 \\
0 \\
-25 \\
-35 \\
+60 \\
+20 \\
+20 \\
+10 \\
+20 \\
-10 \\
+15 \\
+15 \\
+25 \\
+5 \\
-10\end{array}$ \\
\hline
\end{tabular}

* Case 11 , who lost $70^{\circ}$ of mobility of the fixed knee during the trial, had recovered full mobility in both knees when checked 9 months later.

TABLE II

GRADE OF PAIN ON PASSIVE MOVEMENT AT EACH ASSESSMENT

\begin{tabular}{|c|c|c|c|c|c|c|c|c|c|c|c|}
\hline \multirow{2}{*}{$\frac{\text { Knee }}{\text { Week }}$} & \multirow{2}{*}{$\cdots$} & \multicolumn{5}{|c|}{ Fixed } & \multicolumn{5}{|c|}{ Mobile } \\
\hline & & 0 & 4 & 5 & 6 & 8 & 0 & 4 & 5 & 6 & 8 \\
\hline \multirow{4}{*}{ Grade } & 0 & 0 & 1 & 1 & 1 & 5 & 0 & 3 & 4 & 3 & 7 \\
\hline & 1 & 4 & 7 & 8 & 12 & 10 & 7 & 12 & 10 & 10 & 8 \\
\hline & 2 & 11 & 8 & 9 & 5 & 3 & 8 & 2 & 4 & 5 & 3 \\
\hline & 3 & 3 & 2 & 一 & 一 & - & 3 & 1 & - & - & - \\
\hline \multicolumn{2}{|l|}{ Pain Score } & 35 & 29 & 26 & 22 & 16 & 32 & 19 & 18 & 20 & 14 \\
\hline
\end{tabular}

Fig. 1 shows that both the initial and final values were in close agreement in the two groups. As pain on passive movement was the value charted, it is not surprising that for the first week out of plaster, pain was greater in the previously fixed group, but by Week 6 (out of plaster for 2 weeks) there was little difference between the groups. Initially 25 out of the 36 knees were in Grade 2 or 3, and by Week 8 only six knees were in Grade 2 or 3 . It is clear that continuous splintage for 4 weeks has no advantage over intermittent splintage in pain relief and that both techniques were quite effective.

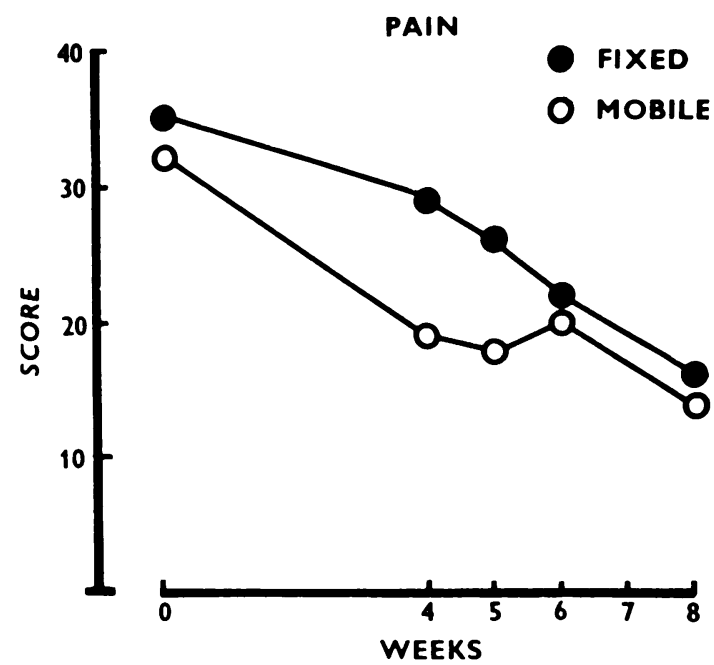

Fig. 1.-Mean pain score for each group, Weeks 0-8.

(2a) Knee Swelling.--In both groups, swelling improved greatly during the trial, and at Week 4 effusion was present in only one subject in each group, whereas originally 21 knees had been in Grade 2 (small effusion). Both techniques appear equally effective (Fig. 2, overleaf). 


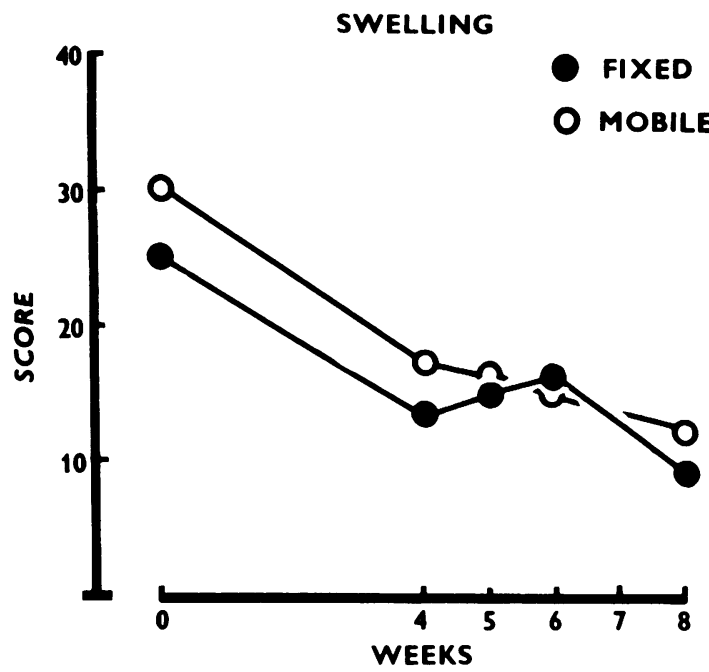

Fig. 2.-Mean swelling scores for each group, Weeks 0-8.

(2b) Knee Circumference.-This was also assessed by actual measurement in $\frac{1}{4}$ inches at the proximal pole of the patella. The changes which occurred were considered to be due both to reduction in joint size (effusion, synovial thickening) and to quadriceps wasting.

Both groups of knees lost fairly similar amounts up to Week 8 , but there was a considerable difference in the final figures (Fig. 3). This loss closely parallels that of thigh circumference and loss of muscle bulk must be largely responsible for the difference.
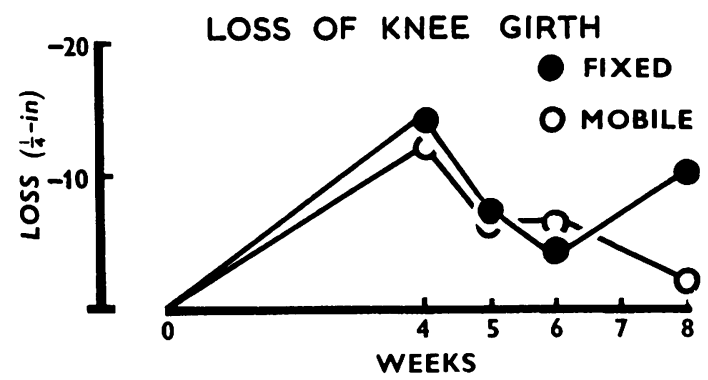

Fig. 3.-Mean loss of knee circumference, measured in 1 -in. units, for each group, Weeks 0-8.

(3) Thigh Circumference.-This was measured in $\frac{1}{4}$ inches 6 in. proximal to the pole of the patella. The total circumference in each group decreased, the loss being double on the immobilized side (Fig. 4). The actual loss was, however, very small, and it suggests that static muscle setting is quite satisfactory in maintaining muscle bulk during immobilization, but that this loss may be reduced by adding knee movement.

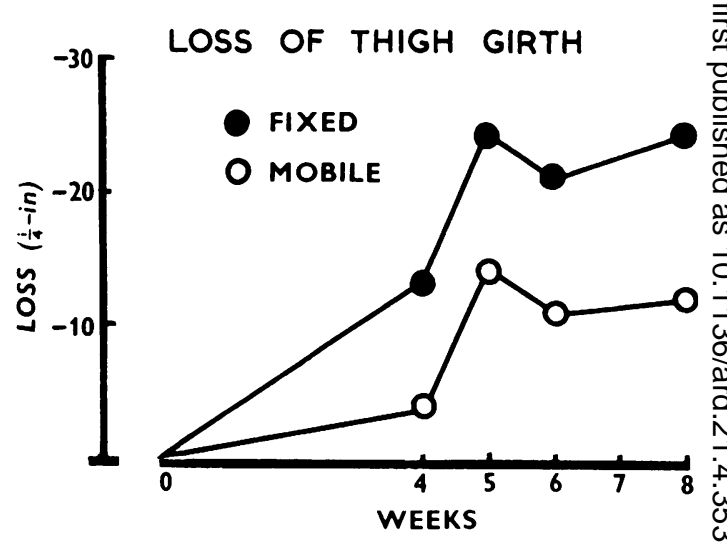

Fig. 4.-Mean loss of thigh circumference, measured in $\frac{1}{4}$-in. units, $\mathrm{O}$ for each group, Weeks 0-8.

(4) Ligamentous Laxity.-All subjects were Grade $\stackrel{\mathbb{}}{\varnothing}$ 0 or 1 at the start and at the end of 4 weeks, and $\stackrel{\mathbb{S}}{3}$ there was little overall change in either group (Table III, opposite).

(5) Local Disease Activity.-Table I shows the both groups were initially very similar in this respect. Both groups improved considerably and syn-? metrically during the trial (Fig. 5), and there is thus no apparent advantage in continuous splintage compared with intermittent splintage in the control of local disease activity. Both are effective.

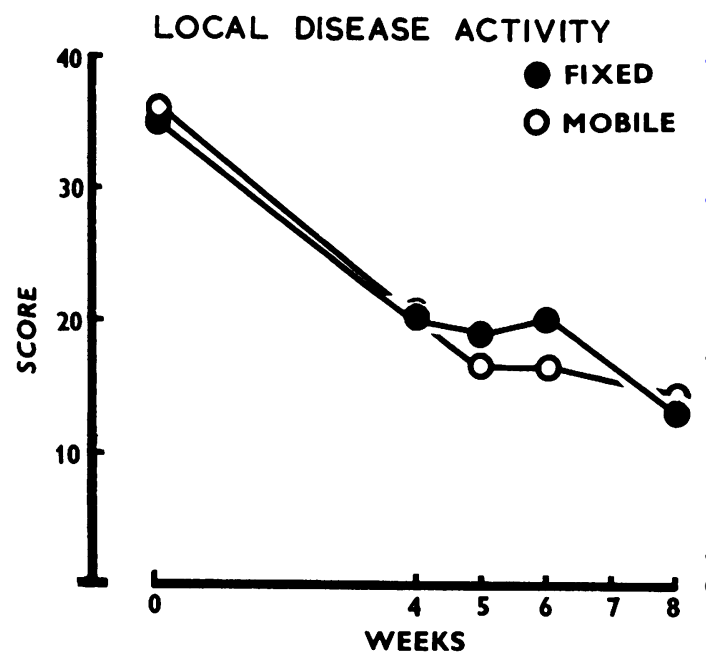

Fig. 5.-Mean local disease activity in each group, Weeks 0-8. 
IMMOBILIZATION OF THE KNEE JOINT IN RHEUMATOID ARTHRITIS

TABLE III

GRADE OF LIGAMENTOUS LAXITY OF FIXED AND MOBILE KNEES AT EACH ASSESSMENT

\begin{tabular}{|c|c|c|c|c|c|c|c|c|c|c|c|c|c|}
\hline \multirow{2}{*}{$\begin{array}{l}\text { Knee } \\
\text { Week }\end{array}$} & \multirow{2}{*}{$\frac{}{\ldots}$} & \multirow{2}{*}{$\frac{\cdots}{\ldots}$} & \multirow{2}{*}{$\begin{array}{l}\cdots \\
\cdots\end{array}$} & \multicolumn{5}{|c|}{ Fixed } & \multicolumn{5}{|c|}{ Mobile } \\
\hline & & & & 0 & 4 & 5 & 6 & 8 & 0 & 4 & 5 & 6 & 8 \\
\hline \multirow{4}{*}{ Grade } & \multirow{2}{*}{\multicolumn{2}{|c|}{ Antero-Posterior }} & 0 & 14 & 16 & 15 & 15 & 14 & 12 & 16 & 15 & 15 & 14 \\
\hline & & & 1 & 4 & 2 & 3 & 3 & 4 & 6 & 2 & 3 & 3 & 4 \\
\hline & \multirow{2}{*}{\multicolumn{2}{|c|}{ Lateral }} & 0 & 12 & 11 & 9 & 10 & 11 & 13 & 10 & 10 & 12 & 14 \\
\hline & & & 1 & 6 & 7 & 9 & 8 & 7 & 5 & 8 & 8 & 6 & 4 \\
\hline
\end{tabular}

(6) Range of Knee Movement.-When the plaster on the fixed side was split at Week 4, not surprisingly the range of movement on that side was considerably reduced in most subjects; none showed a real increase and ten showed a decrease of over $45^{\circ}$. Only one subject in the "mobile" series had a loss of this size at Week 4. Movement gradually increased and by Week 8 the mean range on the fixed side was within $5^{\circ}$ of the initial value. Although the mobile side showed an overall mean gain of over $9^{\circ}$ at the end of the trial, the difference between the two sides is not significant $(t=1 \cdot 745 ; P<0 \cdot 40)$. The mean range is shown in Fig. 6.

The tendency for symmetrical change was marked. If the "fixed" side gained or lost, then so did the "mobile" side. This is shown most clearly by studying the six "fixed" knees which lost $15^{\circ}$ or more during the experiment (Cases 1, 6, 7, 11, 13, 18). In these subjects the paired "mobile" knee behaved differently from the rest of the "mobile" group, in that five of the six also lost movement (Cases 1, 6, $7,13,18)$ and these were the only "mobile" knees to lose any movement. The mean loss for the six mobile knees was $13 \cdot 3^{\circ}$, whilst the remainder of the group showed a mean gain of $20 \cdot 8^{\circ}$. The details of these six subjects are given in Table IV, and it will be seen that in no other way did they differ from the remainder of the group.

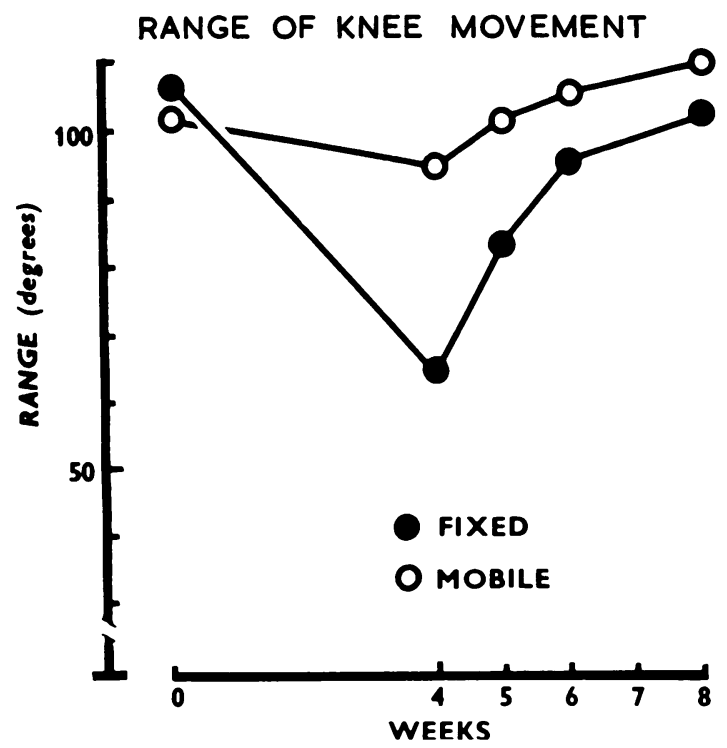

Fig. 6.-Mean range of movement $\left({ }^{\circ}\right)$ in each group, Weeks $0-8$.

It seems clear that some factor other than immobility is important in causing loss of movement, as there is such a marked tendency for both the fixed and the mobile knee in a pair to behave in the same manner.

TABLE IV

CLINICAL PARTICULARS OF SIX PATIENTS WITH MOBILITY LOSS OF $15^{\circ}$ OR MORE AT WEEK 4

\begin{tabular}{|c|c|c|c|c|c|c|c|c|c|c|c|c|}
\hline \multirow{3}{*}{$\begin{array}{l}\text { Case } \\
\text { No. }\end{array}$} & \multicolumn{4}{|c|}{ Range of Movement $\left({ }^{\circ}\right)$} & \multirow{3}{*}{ Sex } & \multirow{3}{*}{$\begin{array}{c}\text { Age } \\
\text { (yrs) }\end{array}$} & \multirow{3}{*}{$\begin{array}{c}\text { Duration } \\
\text { of } \\
\text { Disease } \\
\text { (yrs) }\end{array}$} & \multirow{3}{*}{ S.C.A.T. } & \multirow{3}{*}{$\begin{array}{l}\text { Steroid } \\
\text { Therapy }\end{array}$} & \multirow{3}{*}{$\begin{array}{c}\text { Grade } \\
\text { of } \\
\text { Disease } \\
\text { Activity }\end{array}$} & \multirow{2}{*}{\multicolumn{2}{|c|}{$\begin{array}{c}\text { Radiological } \\
\text { Grading }\end{array}$}} \\
\hline & \multicolumn{2}{|c|}{ Initial } & \multicolumn{2}{|c|}{ Change } & & & & & & & & \\
\hline & Fixed & Mobile & Fixed & Mobile & & & & & & & Fixed & Mobile \\
\hline $\begin{array}{c}1 \\
6 \\
7 \\
11^{*} \\
13 \\
18\end{array}$ & $\begin{array}{l}140 \\
130 \\
105 \\
130 \\
110 \\
110\end{array}$ & $\begin{array}{r}140 \\
145 \\
110 \\
120 \\
90 \\
85\end{array}$ & $\begin{array}{l}-15 \\
-40 \\
-20 \\
-70 \\
-30 \\
-25\end{array}$ & $\begin{array}{l}-10 \\
-25 \\
-35 \\
+10 \\
-10 \\
-10\end{array}$ & $\begin{array}{l}\mathbf{F} \\
\mathbf{F} \\
\mathbf{M} \\
\mathbf{F} \\
\mathbf{F} \\
\mathbf{M}\end{array}$ & $\begin{array}{l}51 \\
69 \\
58 \\
57 \\
63 \\
48\end{array}$ & $\begin{array}{r}26 \\
3 \\
2 \\
3 \\
11 \\
7\end{array}$ & $\begin{array}{l}+ \\
+ \\
+ \\
+ \\
+ \\
+\end{array}$ & $\begin{array}{l}+ \\
+ \\
+ \\
+ \\
-\end{array}$ & $\begin{array}{l}2 \\
2 \\
2 \\
2 \\
2 \\
2\end{array}$ & $\begin{array}{l}0 \\
1 \\
1 \\
2 \\
2 \\
3\end{array}$ & $\begin{array}{l}0 \\
1 \\
1 \\
1 \\
2 \\
2\end{array}$ \\
\hline
\end{tabular}

* Case 11 had recovered full mobility in both knees 9 months later. 
All the knees which lost $20^{\circ}$ or more during the trial initially had a range of movement of $110^{\circ}$ or more and only one of these finished with a range below $75^{\circ}$ (Subject 11, fixed knee, initial range $130^{\circ}$, final range $60^{\circ}$ ). Four knees in three subjects had restricted movement initially $\left(30,35,65,65^{\circ}\right)$ and all gained substantially in movement during the trial $\left(+60,+45,+35,+15^{\circ}\right)$. In fact, of the thirteen knees with an initial range of movement of $90^{\circ}$ or less, only two knees lost any mobility at all (each lost $10^{\circ}$ ).

It will be seen that, although there was some loss of mobility in some knees, this loss was usually insufficient to cause any real functional disability and when the knee was initially very restricted, an increase in movement is to be expected, presumably through release of muscle spasm.

(7) Erythrocyte Sedimentation Rate.-This showed, in general, a steady fall during the trial period. The subjects with the greatest changes were Cases 4 and 7 in whom it improved, and Cases 12, 17 , and 18 , in whom it deteriorated. These findings are not correlated with changes in knee mobility.

(8) Radiological Grading.-All subjects were in Grades $0,1,2$, or 3 . Five knees, in three subjects, were in Grade 0 and the mobility changes in these knees did not differ from the main group. Two knees, in separate subjects, were in Grade 3. In Case 18, the "fixed" knee was Grade 3 and lost $25^{\circ}$ over the trial, but the "mobile" knee (Grade 2) also lost $10^{\circ}$ over this period. In Case 17, the "mobile" knee (Grade 3) gained $5^{\circ}$, and so did the fixed knee (Grade 2).

(9) Disease Activity.-Thirteen subjects had general disease activity Grade 2 and the other five Grade 3.

The five in Grade 3 had changes of $-5,+45$, $-5,+5$, and $+10^{\circ}$ (mean $+10^{\circ}$ ) in the fixed knee and of $+25,+60,+15,+15,+25^{\circ}\left(\right.$ mean $\left.+28^{\circ}\right)$ in the mobile knee. These gains are greater than for the main series and these subjects did decidedly better than the rest of the series.

The large improvement is mainly due to the inclusion of Case 8 , who showed the biggest gain in both knees $\left(+45^{\circ}\right.$ and $\left.+60^{\circ}\right)$, and who started with a range of movement of only $30^{\circ}$ and $35^{\circ}$. If this case is excluded, the difference from the main series is not significant.

All these five subjects in Grade 3 were S.C.A.T. positive and four of them were receiving steroid therapy.

\section{Discussion}

Some authorities (Ropes, 1961) consider it $\frac{\square}{\omega}$. unsafe to immobilize an active rheumatoid joint for any length of time, and insist that such joints $\underset{\vec{\sigma}}{\overrightarrow{0}}$ must be moved frequently, at least several times a 0 day. Our experiment shows that a knee joint with active disease in a patient with "definite R.A." (A.M.A. classification) may safely be immobilized $\mathbb{\Omega}$ for up to 4 weeks. Other writers (Duthie, 1951; Kelly, 1953; Kindersley, 1936; Partridge and Duthie, 1960) regard prolonged complete immobili-. zation of such joints as essential to control local $\overrightarrow{\vec{\omega}}$ disease activity. We have demonstrated that joints $\stackrel{\omega}{\sigma}$ given complete rest for 4 weeks gained no advantage at any time during an 8-week period over joints given 3 days' rest followed by daily movement combined with rest in bed. Both techniques are $\vec{\omega}$ quite effective in the relief of pain and the control on of disease activity.

The marked symmetry of the changes which occurred in each pair of knee joints indicate that $\vec{\square}$ general factors are probably of greater importance $\mathbb{\mathbb { }}$ than local treatment in determining loss of joint $\frac{\mathbb{}}{3}$ mobility. However, the patients who lost or gained most did not appear to differ from the rest of the series, although the figures suggest that $\vec{\varphi}$ subjects with the most active disease, of the mos recent onset, do rather better than the others.

\section{Summary}

Eighteen patients with definite rheumatoid arthritis and symmetrically involved knee joints showing $\stackrel{2}{\Rightarrow}$ active disease, were treated in plaster splints. One knee of each pair was immobilized completely for 4 weeks, and the plaster on the other knee was split after 3 days so that daily assisted movements could be performed. The range of movement of the joints was assessed periodically for a further 4 weeks.

There was no significant difference between the 3 . mobility of the two knees at the end of the trial period. Both techniques thus appear to be equally satisfactory and equally safe.

We wish to acknowledge the statistical advice given by $\frac{7}{O}$ Miss F. Bier of the Rheumatism Research Unit, University of Manchester.

\section{REFERENCES}

Duthie, J. J. R. (1951). Practitioner, 166, 22.

Kelly, M. (1953). Med. J. Aust., 2, 95.

Kindersley, C. E. (1936). Proc. roy. Soc. Med., 29, 237.

Partridge, R. E. H. and Duthie, J. J. R. (1960). Ann. rheum. Dis., 19, 381.

Ropes, M. W. (1961). Med. Clin. N. Amer., 45, 1197. 
Immobilisation de l'articulation du genou dans l'arthrite rhumatismale

\section{RÉSUMÉ}

On étudia 18 malades souffrant d'arthrite rhumatismale définie et ayant les deux genoux atteints symétriquement d'un processus inflammatoire actif. On appliqua un emplâtre sur tous les genoux. Un genou de chaque paire fut ainsi immobilisé pendant 4 semaines, tandis que le plâtre sur l'autre genou fut fendu après 3 jours pour permettre des mouvements assistés quotidiens. Pendant 4 semaines après cette expérience on détermina périodiquement l'amplitude des mouvements articulaires.

On ne trouva pas de différence appréciable entre les mobilités des deux genoux à la fin de la période expérimentale. Les deux procédés paraissent donc également satisfaisants et également sans danger.
Inmovilización de la articulación de la rodilla en la artritis reumatoide

Sumario

En 18 enfermos con artritis reumatoide definida y con ambas rodillas afectas activa y simétricamente se aplicó un enyesado a todas las rodillas. Una de cada pareja de rodillas permaneció inmovilizada completamente durante 4 semanas, mientras que en la otra el enyesado fué hendido después de 3 días para permitir diariamente movimientos asistidos. Durante las 4 semanas que siguieron este experimento se determinó periodicamente la amplitud de los movimientos articulares.

Ninguna diferencia apreciable en la movilidad entre las rodillas diferentemente tratadas fué encontrada al cabo del período de investigación. Ambos procedimientos parecen pués igualmente satisfactorios e igualmente innocuos. 